\title{
Pengaruh Current Ratio Dan Debt To Equity Ratio \\ Terhadap Return On Equity Pada Perusahaan Food And Baverage Yang Terdaftar Di Indonesia Stock Exchange (IDX)Tahun 2012-2016
}

\author{
Kusminaini Armin ${ }^{1}$, Maryandhi ${ }^{2}$ \\ ${ }^{1}$ Fakultas Ekonomi Universitas Tridinanti Palembang \\ ${ }^{2}$ Fakultas Ekonomi Universitas Tridinanti Palembang
}

\begin{abstract}
ABSTRAK
Tujuan yang hendaknya dicapai dalam penelitian ini adalah untuk mengetahui seberapa besar pengaruh Current Ratio, Debt to Equity Ratio terhadap Return On Equity pada perusahaan Food and Baverage yang terdaftar di IDX tahun 2012-2016. Teknik pengumpulan data dilakukan dengan kegiatan dokumentasi laporan keuangan perusahaan dari tahun 2012 sampai dengan tahun 2016 kemudian diolah lebih lanjut untuk menghitung rasio keuangan yang dijadikan sebagai sampel penelitian. Hasil penelitian ini menunjukkan bahwa nilai nilai koefisien determinasi ( $R$ square) sebesar 0,417. Dari Nilai tersebut dapat dilakukan penafsiran bahwa pengaruh Current Ratio $\left(X_{1}\right)$ dan Debt to Equity Ratio $\left(\mathrm{X}_{2}\right)$, terhadap Return On Equity $(\mathrm{Y})$ sebesar $41,7 \%$. Sedangkan sisanya sebesar $58,3 \%$ dipengaruhi oleh faktor-faktor lain yang tidak diteliti dalam penelitian ini. Dari hasil statistik juga menunjukkan bahwa Current Ratio $\left(X_{1}\right)$ secara parsial tidak memiliki pengaruh yang signifikan terhadap Return On Equity $(Y)$. Sesangkan Debt to Equity Ratio $\left(\mathrm{X}_{2}\right)$, secara parsial berpengaruh positif dan signifikan terhadap Return On Equity $(Y)$. Secara simultan Current Ratio $\left(\mathrm{X}_{1}\right)$ dan Debt to Equity Ratio $\left(\mathrm{X}_{2}\right)$, mempunyai pengaruh positif dan signifikan terhadap Return On Equity $(\mathrm{Y})$. Hal ini dapat dibuktikan melalui Uji statistik F, dimana nilai F.sig sebesar 0,000 lebih kecil dari tingkat signifikan $5 \%(\alpha=0,05)$ maka $\mathrm{H}_{\mathrm{a}}$ diterima dan $\mathrm{H}_{0}$ ditolak.
\end{abstract}

Kata Kunci : Current Ratio, Debt to Equity Ratio, dan Return On Equity.

\section{A. Pendahuluan}

Laporan keuangan merupakan sebuah media informasi yang mencatat, merangkum segala akivitas perusahaan untuk menggambarkan kinerja perusahaan tersebut. Evaluasi kineja keuangan dapat di lihat menggunakan analisis rasio keuangan. Rasio-rasio yang digunakan untuk menilai kinerja keuangan perusahaan seperti rasio likuiditas, rasio leverage, rasio aktivitas dan rasio profitabilitas. Analisis rasio memungkinkan manajer keuangan dan pihak yang berkepentingan untuk menganalisa kondisi keuangan apakah menunjukkan kondisi sehat atau tidaknya suatu perusahaan.

$$
\text { Analisis rasio juga }
$$

menghubungkan unsur-unsur rencana dan perhitungan laba rugi sehingga dapat mengukur efektivitas dan efisiensi perusahaan. Laba perusahaan itu sendiri dapat diukur melalui Return On Equity (ROE) perusahaan. Karena ROE mempunyai hubungan positif dengan perubahan laba. ROE digunakan untuk mengukur efekivitas perusahaan didalam menghasilkan keuntungan dengan memanfaatkan ekuitas yang dimilkinya. ROE merupakan rasio antara laba setelah pajak (EAT) dengan total ekuitas. Alat ukur kinerja suatu perusahaan yang paling popular antara penanam modal dan manajer senior adalah hasil atas hak pemegang saham adalah Return On Equity (ROE). Semakin tinggi laba perusahaan maka akan semakin tinggi ROE, besarnya laba perusahaan juga dipengaruhi oleh beberapa faktor seperti Current Ratio (CR) dan Debt to Equity Ratio (DER). 
Mengingat kondisi ekonomi yang tidak stabil, maka dapat mempengaruhi kondisi laba perusahaan. Laba perusahaan yang harusnya meningkat, sebaliknya mengalami penurunan. $\mathrm{Di}$ pasar saham, perusahaan yang telah go publik dikelompokkan kedalam beberapa sektor industri. Dari beberapa pengelompokkan tersebut, sektor industri manufaktur memiliki jumlah perusahaan yang paling besar, karena merupakan industri yang bergerak menghasilkan barang dan merupakan emiten terbesar dibanding industri lain.

Kondisi itulah yang menjadi sebab penelitian ini dilakukan, disamping alasan lain yaitu untuk mengetahui apakah penelitian ini konsisten dengan penelitian sebelumnya. Penelitian dilakukan pada perusahaan yang sahamnya terdaftar di Indonesia Stock Exchange (IDX) pada periode 2012-2016 dan termasuk dalam kelompok industri manufaktur Food and Baverage.

Berikut ini adalah data mengenai Current Ratio (CR), Debt to Equity Ratio (DER), dan Return On Equity (ROE) yang terdaftar di Indonesia Stock Exchange (IDX) pada tahun 2012-2016, sebagai berikut :

\section{Perusahaan Food and Baverage yang terdaftar Di IDX Periode 2012-2016}

\begin{tabular}{|c|c|c|c|c|c|c|c|}
\hline NO & NAMA PERUSAHAAN & RASIO & 2012 & 2013 & 2014 & 2015 & 2016 \\
\hline \multirow{3}{*}{1} & \multirow{3}{*}{ PT DELTA DJAKARTA TbK } & CR & 526.46 & 470.54 & 447.32 & 642.37 & 712.54 \\
\hline & & DER & 0.25 & 0.28 & 0.3 & 0.22 & 0.22 \\
\hline & & ROE & 35.68 & 39.98 & 37.68 & 22.6 & 18.54 \\
\hline \multirow{3}{*}{2} & \multirow{3}{*}{$\begin{array}{l}\text { PT INDOFOOD CBP SUKSES } \\
\text { MAKMUR TbK }\end{array}$} & CR & 276.25 & 241.06 & 218.32 & 232.6 & 242.34 \\
\hline & & DER & 0.48 & 0.6 & 0.66 & 0.62 & 0.58 \\
\hline & & ROE & 19.04 & 16.85 & 16.83 & 17.84 & 16.56 \\
\hline \multirow{3}{*}{3} & \multirow{3}{*}{$\begin{array}{l}\text { PT INDOFOOD SUKSES MAKMUR } \\
\text { Tbk }\end{array}$} & CR & 200.32 & 166.73 & 180.74 & 170.53 & 166.18 \\
\hline & & DER & 0.74 & 1.04 & 1.08 & 1.13 & 1.06 \\
\hline & & ROE & 14 & 8.9 & 12.48 & 8.6 & 9.13 \\
\hline \multirow{3}{*}{4} & \multirow{3}{*}{$\begin{array}{l}\text { PT MULTI BINTANG INDONESIA } \\
\text { Tbk }\end{array}$} & $\mathbf{C R}$ & 58.05 & 97.75 & 51.39 & 58.42 & 60.68 \\
\hline & & DER & 2.49 & 0.8 & 3.03 & 1.74 & 3.56 \\
\hline & & ROE & 137.46 & 118.6 & 143.53 & 64.83 & 130.42 \\
\hline \multirow{3}{*}{5} & \multirow{3}{*}{ PT MAYORA INDAH Tbk } & CR & 276.11 & 244.34 & 208.99 & 236.53 & 220.67 \\
\hline & & DER & 1.71 & 1.47 & 1.51 & 1.18 & 1.15 \\
\hline & & ROE & 24.27 & 26.87 & 9.99 & 24.07 & 15.99 \\
\hline \multirow{3}{*}{6} & \multirow{3}{*}{$\begin{array}{l}\text { PT NIPPON INDOSARI CORPINDO } \\
\text { Tbk }\end{array}$} & $\mathbf{C R}$ & 112.46 & 113.64 & 136.64 & 205.34 & 282.4 \\
\hline & & DER & 0.81 & 1.32 & 1.23 & 1.28 & 1.06 \\
\hline & & ROE & 22.37 & 20.07 & 19.64 & 22.76 & 15.02 \\
\hline \multirow{3}{*}{7} & \multirow{3}{*}{ PT SEKAR LAUT Tbk } & CR & 141.48 & 123.38 & 118.38 & 119.25 & 140.86 \\
\hline & & DER & 0.93 & 1.16 & 1.16 & 1.48 & 1.3 \\
\hline & & ROE & 6.15 & 8.19 & 10.75 & 13.2 & 8.99 \\
\hline \multirow{3}{*}{8} & \multirow{3}{*}{$\begin{array}{l}\text { PT TIGA PILAR SEJAHTERA } \\
\text { FOOD Tbk }\end{array}$} & CR & 126.95 & 175.03 & 266.33 & 162.29 & 218.6 \\
\hline & & DER & 0.9 & 1.13 & 1.05 & 1.28 & 1.18 \\
\hline & & ROE & 12.47 & 14.71 & 10.52 & 9.42 & 10.38 \\
\hline \multirow{3}{*}{9} & \multirow{3}{*}{$\begin{array}{l}\text { PT ULTRAJAYA MILK INDUSTRY } \\
\text { \& TRADING COMPANY TbK }\end{array}$} & $\mathbf{C R}$ & 201.82 & 247.01 & 334.46 & 374.55 & 522.34 \\
\hline & & DER & 0.44 & 0.4 & 0.29 & 0.27 & 0.19 \\
\hline & & ROE & 21.08 & 16.13 & 12.51 & 18.7 & 16.6 \\
\hline \multirow{3}{*}{10} & \multirow{3}{*}{$\begin{array}{l}\text { PT WILMAR CAHAYA INDONESIA } \\
\text { Tbk }\end{array}$} & CR & 102.71 & 163.22 & 146.56 & 153.47 & 185.36 \\
\hline & & DER & 1.22 & 1.02 & 1.39 & 1.32 & 0.92 \\
\hline & & ROE & 12.59 & 12.32 & 7.63 & 16.65 & 17.45 \\
\hline
\end{tabular}

Sumber : ICMD tahun 2012, 2013, 2014, 2015, 2016 dan annual report 2016 (www.idx.co.id) 
Berdasarkan Tabel diatas menunjukkan bahwa adanya peningkatan dan penurunan CR, DER, diseluruh perusahaan Food and Baverage yang terdaftar di IDX dari terhadap ROE yang tidak stabil tahun 2012-2016.

Rata-rata CR, DER, dan ROE

Pada Perusahaan Food and Baverage yang terdaftar Di IDX

Periode 2012-2016

\begin{tabular}{|c|r|r|r|r|l|}
\hline \multirow{2}{*}{ Variabel } & \multicolumn{5}{|c|}{ Tahun } \\
\cline { 2 - 6 } & \multicolumn{1}{|c|}{$\mathbf{2 0 1 2}$} & \multicolumn{1}{c|}{$\mathbf{2 0 1 3}$} & \multicolumn{1}{c|}{$\mathbf{2 0 1 4}$} & \multicolumn{1}{c|}{$\mathbf{2 0 1 5}$} & \multicolumn{1}{c|}{$\mathbf{2 0 1 6}$} \\
\hline CR & 202.261 & 204.27 & 210.913 & 235.535 & 275.197 \\
\hline DER & 0.997 & 0.922 & 1.170 & 1.052 & 1.122 \\
\hline ROE & 30.511 & 28.262 & 28.156 & 21.867 & 25.908 \\
\hline
\end{tabular}

Sumber :ICMD tahun 2012, 2013, 2014, 2015, 2016 dan annual report 2016 (www.idx.co.id )

Berdasarkan Tabel diatas menunjukkan bahwa rata-rata $\mathrm{CR}$ mengalami perubahan yang stabil yang terus mengalami peningkatan pada tahun 2012-2016. Hal ini berarti apabila tingkat likuiditas (CR) dari tahun 2012 sampai 2016 meningkat yang semakin besar angka rasio likuiditas, akan semakin baik bagi investor. Perusahaan yang memiliki rasio likuiditas besar atau semakin naik para investor akan berdatangan dan akan berdampak pada harga saham yang cenderung naik karena besar peminatnya, walaupun kenaikannya tidak terlalu besar.

Pada rata-rata DER menunjukkan perubahan yang tidak konsisten, terjadi peningkatan dan penurunan pada tahun 202-2016. Hal ini berarti apabila DER semakin rendah maka kemampuan perusahaan untuk mendapatkan laba semakin tinggi. Begitu pula sebaliknya, semakin tinggi DER maka kemampuan perusahaan untuk mendapatkan laba semakin rendah.

Sedangkan rata-rata ROE setiap tahunnya menunjukkan angka yang mengalami peningkatan dan penurunan dari tahun ke tahun walaupun kecil. Hal ini mengindikasikan bahwa kemampuan perusahaan dalam menghasilkan laba dengan memanfaatkan ekuitas yang dimilikinya masih belum stabil.

Oleh sebab itu maka dilakukan penelitian dengan judul penelitian "Pengaruh Current Ratio dan Debt to Equity Ratio terhadap Return On Equity pada perusahaan Food and Baverage yang terdaftar di Indonesia Stock Exchange (IDX) tahun 2012-2016.

\section{B. Rumusan Masalah}

Sesuai dengan latar belakang masalah yang telah diuraikan, maka rumusan masalah dalam penelitian ini adalah sebagai berikut :

1. Apakah Current Ratio dan Debt to Equity Ratio secara simultan dan secara parsial berpengaruh terhadap Return On Equity (ROE) pada perusahaan manufaktur di Indonesia Stock Exchange (IDX) tahun 2012-2016?

2. Berapa besar pengaruh Current Ratio dan Debt to Equity Ratio secara simultan dan secara parsial berpengaruh terhadap Return On Equity (ROE) pada perusahaan manufaktur di Indonesia Stock Exchange (IDX) tahun 2012-2016? 
C. Landasan Teori

- $\quad$ Return On Equity (ROE)

\begin{abstract}
Profitabilitas menurut Sofyan (2011:304), "menggambarkan kemampuan perusahaan mendapatkan laba melalui semua kemampuan, dan sumber yang ada seperti kegiatan penjualan, kas, modal, jumlah karyawan, jumlah cabang, dan sebagainya".
\end{abstract}

Menurut Sutrisno (2007:223), "hasil perhitungan Return On Equity sangat dipengaruhi oleh perolehan laba perusahaan, sehingga semakin tinggi hasil yang diperoleh dari perhitungan rasio ini, maka akan menunjukkan semakin baik kedudukan perusahaan".
Rasio profitabilitas yang
menggambarkan $\quad$ kemampuan perusahaan mengahasilkan laba dapat disebut juga Operating Ratio. Keuntungan yang akan diraih dari investasi yang akan ditanamkan merupakan pertimbangan utama bagi sebuah perusahaan dalam rangka pengembangan bisnisnya. Disamping itu sehubungan dengan masalah dari ketidakpastian dari kondisi yang akan dihadapi maka besarnya investasi yang ditanamkan harus diperhitungkan dalam pengambilan kebutuhan dana.

Return on Equity dapat dirumuskan sebagai berikut :
- $\quad$ Current Ratio (CR)

Likuiditas menurut Hery (2016:142), merupakan "kemampuan perusahaan dalam memenuhi kewajiban atau membayar utang jangka pendeknya". Sedangkan menurut James C. Van Horne dan John M. Wachowicz, Jr (2012:167), "likuiditas digunakan untuk mengukur kemampuan perusahaan untuk memenuhi liabilitas jangka pendeknya". Rasio ini membandingkan liabilitas jangka pendek dengan sumber daya jangka pendek yang tersedia untuk memenuhi liabilitas tersebut. Current Ratio (CR) digunakan untuk membandingkan aktiva lancar dengan hutang lancar yang harus dibayarkan perusahaan. Apabila tingkat CR tinggi, maka perusahaan dikatakan mampu untuk membayar

\section{Earning After Tax}

\section{Total Equity}

segala kewajiban jangka pendeknya kepada kreditur. Namun CR yang tinggi tidak juga selalu baik karena akan menunjukkan bahwa terdapat aktiva lancar yang berlebih yang tidak digunakan secara efektif sehingga dapat menyebabkan berkurangnya keuntungan atau tingkat profitabilitas, yang juga dapat mengakibatkan semakin kecilnya Return On Equity (ROE).

Menurut Wiratna (2017:60), "Current Ratio merupakan rasio yang digunakan untuk mengukur kemampuan perusahaan dalam membayar kewajiban jangka pendeknya dengan menggunakan aktiva lancar yang dimiliki”.

Current Ratio dapat dirumuskan sebagai berikut : 
Current Ratio :

\section{Current Asset}

Current Liability

\section{- Debt to Equity Ratio (DER)}

Menurut Sofyan (2011:304), "rasio ini mengambarkan kemampuan perusahaan dalam membayar kewajiban jangka panjangnya atau kewajiban-kewajibannya apabila perusahaan dilikuidasi".

Debt to Equity Ratio menurut Hery (2016:143), merupakan "rasio yang digunakan untuk mengukur besarnya proporsi hutang terhadap modal". Rasio ini memberikan petunjuk umun tentang kelayakan kredit dan resiko keuangan debitor.

Debt to Equity Ratio (DER) merupakan "perbandingan rasio antara hasil hutang secara keseluruhan

Debt to Equity Ratio :

- Kerangka Berfikir

Current Ratio

yang

mengakibatkan perubahan jumlah aktiva lancar atau hutang lancar, baik masing-masing atau keduanya akan mengakibatkan perubahan $\mathrm{CR}$, yang berarti mengakibatkan perubahan tingkat likuiditas. Nilai likuiditas yang terlalu tinggi berdampak kurang baik terhadap earning power karena adanya kelebihan modal kerja yang dibutuhkan, kelebihan ini akan menurunkan kesempatan memperoleh keuntungan. Dengan demikian sangat dimungkinkan hubungan $\mathrm{CR}$ dengan ROE adalah negatif. Semakin tinggi $\mathrm{CR}$ maka semakin rendah tingkat $\mathrm{ROE}$, perbandingan terbalik antara profitabilitas dengan likuiditas.

Debt to Equity Ratio merupakan rasio yang membandingkan utang dengan modal sendiri yang dimiliki oleh perusahaan" (Munawir, 2007:239). Hasil DER semakin tinggi, maka akan menujukkan semakin tinggi pendanaan yang disediakan pemegang saham bagi perusahaan dan apabila semakin rendah hasil rasio ini maka akan semakin baik kemampuan perusahaan dalam membayar kewajiban jangka panjangnya. "Besarnya hutang maksimal yang dimiliki perusahaan harus sama dengan modal sendiri atau dengan kata lain Debt to Equity Ratio nya maksimal sebesar 100\%" (Sutrisno, 2007:218).

Debt to Equity Ratio dapat dirumuskan sebagai berikut :

Total Hutang

Total Modal Sendiri

perusahaan dengan total ekuitas. Debt to Equity Ratio merupakan Financial Leverage yang dipertimbangkan sebagai variabel keuangan karena secara teoritis menunjukkan rasio suatu perusahaan sehingga berdampak pada ketidakpastian harga saham. Debt to Equity Ratio yang tinggi mempunyai dampak yang buruk terhadap kinerja perusahaan karena tingkat utang yang semakin tinggi berarti beban bunga akan semakin besar yang berarti mengurangi keuntungan, Sebaliknya, tingkat Debt to Equity Ratio yang rendah menunjukkan kinerja yang semakin baik, karena menyebabkan tingkat pengembalian yang semakin tinggi.

Tinggi rendah DER akan mempengaruhi tingkat pencapaian ROE yang dicapai oleh perusahaan. Jika biaya yang ditimbulkan oleh 
pinjaman (cost of debt) lebih kecil daripada biaya modal sendiri (cost of equity), maka sumber dana yang berasal dari pinjaman atau hutang akan lebih efektif dalam menghasilkan laba (meningkatkan Return On Equity) demikian sebaliknya.

Model kerangka berpikir menggambarkan variabel bebas yang terdiri dari Current Ratio $\left(\mathrm{X}_{1}\right)$, dan Debt to Equity Ratio $\left(\mathrm{X}_{2}\right)$ akan mempengaruhi variabel terikat yaitu Return On Equity (Y) baik secara simultan maupun parsial. Sedangkan variabel bebas lainnya berasal dari faktor lain $(\boldsymbol{\varepsilon})$ :

\section{Kerangka Berpikir}

Pengaruh Current Ratio, Debt to Equity Ratio Terhadap Return On Equity

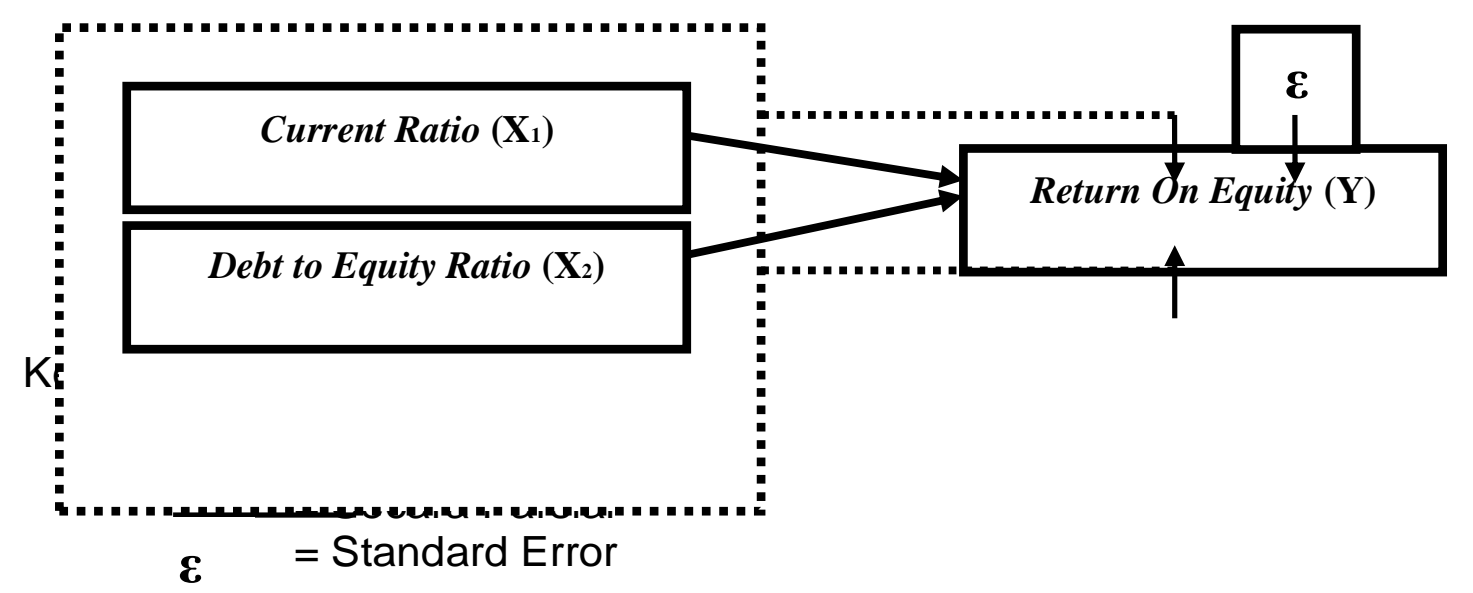

\section{- Hipotesis}

1. Diduga Current Ratio dan Debt to Equity Ratio secara simultan berpengaruh signifikan terhadap Return On Equity (ROE) pada perusahaan Food and Baverage di Indonesia Stock Exchange (IDX) tahun 2012-2016.

2. Diduga Current Ratio dan Debt to Equity Ratio secara parsial berpengaruh signifikan terhadap Return On Equity (ROE) pada perusahaan Food and Baverage di Indonesia Stock Exchange (IDX) tahun 2012-2016.

\section{Metode Penelitian}

Penelitian ini dilakukan pada perusahaan Food and Baverage yang terdaftar di Indonesia Stock Exchange (IDX) pada website www.idx.co.id. Dalam penelitian ini penulis menggunakan data sekunder. Data sekunder yang digunakan dalam penelitian ini terdiri dari data keuangan perusahaan yang diperoleh dari laporan tahunan perusahaan Food and Baverage tahun 2012-2016 yang di unduh dari website resmi (http://www.idx.co.id).

Dalam penelitian ini, peneliti menggunakan data dokumentasi dalam melakukan penelitian ini adalah berupa laporan keuangan serta informasi-informasi yang didapat dari masing-masing Perusahaan Food and Baverage yang terdaftar di Indonesia Stock Exchange (IDX). Sampel dalam penelitian ini adalah perusahaan perkebunan yang terdaftar di IDX dari tahun 2013-2016 yang memenuhi kriteria sampel penelitian ini .

Adapun kriteria sampel dalam penelitian ini yaitu perusahaan perkebunan yang memiliki laporan keuangan lengkap dari tahun 2012- 
2016. Ada 15 (lima Belas) perusahaan Food and Baverage yang terdaftar di Indonesia Stock Exchange (IDX) tahun 2016. Dari ke-15 perusahaan ini hanya ada 10 (sepuluh) perusahaan yang memenuhi kriteria menjadi sampel dalam penelitian ini. Berikut daftar nama perusahaan Food and Baverage yang menjadi sampel dalam penelitian ini:

Daftar Nama Perusahaan Food and Baverage
\begin{tabular}{|c|l|}
\hline No & \multicolumn{1}{|c|}{ Nama Perusahaan } \\
\hline 1 & Delta Djakarta Tbk. \\
\hline 2 & Indofood CBP Sukses makmur Tbk. \\
\hline 3 & Indofood Sukses makmur Tbk. \\
\hline 4 & Mayora Indah Tbk. \\
\hline 5 & Multi Bintang Indonesia Tbk. \\
\hline 6 & Nippon Indosari Corpindo Tbk. \\
\hline 7 & Sekar Laut Tbk. \\
\hline 8 & Tiga Pilar Sejahtera Food Tbk. \\
\hline & Ultrajaya milk Industry \& Trading Co. \\
\hline 9 & Tbk. \\
\hline 10 & Wilmar Cahaya Indonesia Tbk. \\
\hline
\end{tabular}

Sumber : ICMD (www.idx.co.id)

Variabel dalam penelitian ini adalah Variabel independen $(\mathrm{X}): \mathrm{X}_{1}$ Current Ratio (CR), $\mathrm{X}_{2}$ Debt to Equity Ratio (DER). Variabel dependen (Y): $\mathrm{Y}$ (Return On Equity). Uji statistik menggunakan Regresi Linier Berganda yang sebelumnya harus menggunakan uji asumsi klasik, apabila sudah memenuhi syarat maka dilanjutkan dengan Regresi Linier Berganda. Pengujian hipotesis Uji Koefisien Regresi Secara Parsial (Uji t) dan Uji Koefisien Regresi Secara Bersama-sama (Uji F), Analisis Korelasi Ganda, dan Uji Koefisien Determinasi $\left(R^{2}\right)$.

\section{E. Pembahasan}

- Analisis Pengaruh Current Ratio dan Debt to Equity Ratio Secara Simultan Terhadap Return On Equity Perusahaan Food and Baverage

Berdasarkan hasil output SPSS versi 17.0 terlihat bahwa pengaruh secara simultan dua variabel independen tersebut (CR dan DER) terhadap ROE seperti ditunjukkan pada tabel sebagai berikut :

\section{Hasil Uji F (Simultan)}

ANOVA $^{\text {b }}$

\begin{tabular}{|ll|r|r|r|r|r|}
\hline \multicolumn{1}{|l|}{} & Sum of & Squares & df & Mean Square & F & Sig. \\
\hline 1 & Regression & 22369.651 & 2 & 11184.825 & 16.827 & $.000^{\mathrm{a}}$ \\
& Residual & 31240.125 & 47 & 664.684 & & \\
& Total & 53609.776 & 49 & & & \\
\hline
\end{tabular}

a. Predictors: (Constant), DER, CR 
ANOVA $^{\mathrm{b}}$

\begin{tabular}{|ll|c|r|r|r|r|}
\hline Model & \multicolumn{1}{|c|}{$\begin{array}{c}\text { Sum of } \\
\text { Squares }\end{array}$} & df & Mean Square & F & Sig. \\
\hline 1 & Regression & 22369.651 & 2 & 11184.825 & 16.827 & $.000^{\mathrm{a}}$ \\
& Residual & 31240.125 & 47 & 664.684 & & \\
Total & 53609.776 & 49 & & & \\
\hline
\end{tabular}

a. Predictors: (Constant), DER, CR

b. Dependent Variable: ROE

Sumber : Hasil pengolahan data dengan program SPSS 17.0

Berdasarkan tabel hasil pengujian hipotesis secara simultan yang telah dilakukan dengan menggunakan program SPSS versi 17.0 di atas, nilai F hitung dari hasil uji-F sebesar 16,827 dengan tingkat signifikansi 0,000 . Oleh karena $F_{\text {hitung }}>F_{\text {tabel }}(16,827>3,20)$ dan nilai signifikansi lebih kecil dari taraf signifikansi $0,05 \quad(5 \%)$ maka keputusan yang diambil adalah menolak $\mathrm{H}_{0}$ dan menerima $\mathrm{H}_{\mathrm{a}}$ sehingga dapat dinyatakan bahwa terdapat pengaruh yang signifikan antara Current Ratio dan Debt to Equity Ratio terhadap Return On Equity pada perusahaan manufaktur.

Selain itu, dari hasil pengujian koefisien determinasi ( $R$ Square) diperoleh bahwa nilai koefisien determinasi dapat dilihat dari nilai tabel $\mathrm{R}$ Square yaitu sebesar 0,417 atau
$41,7 \%$, artinya pengaruh Current Ratio dan Debt to Equity Ratio terhadap Return On Equity pada perusahaan manufaktur adalah sebesar $41,7 \%$, sedangkan sisanya sebesar $58,3 \%$ dipengaruhi oleh variabel lain diluar variabel dalam penelitian ini.

\section{- Analisis Pengaruh Current Ratio dan Debt to Equity Ratio Secara Parsial Terhadap Return On Equity Perusahaan Food and Baverage}

Berdasarkan hasil output SPSS versi 17.0 terlihat bahwa pengaruh secara parsial dua variabel independen tersebut ( $C R$ dan DER) terhadap ROE seperti ditunjukkan pada tabel sebagai berikut :

\section{Hasil Uji t (Parsial)}

Coefficients $^{a}$

\begin{tabular}{|l|r|r|r|r|r|}
\hline \multirow{2}{*}{ Model } & \multicolumn{2}{|c|}{ Unstandardized Coefficients } & Standardized Coefficients & & \\
\cline { 2 - 5 } & \multicolumn{1}{|c|}{$\mathrm{B}$} & \multicolumn{1}{c|}{ Std. Error } & Beta & \multicolumn{1}{c|}{ Sig. } \\
\hline 1 (Constant) & -28.716 & 14.390 & & -1.996 & .052 \\
CR & .063 & .034 & .274 & 1.866 & .068 \\
DER & 39.381 & 7.319 & .791 & 5.381 & .000 \\
\hline
\end{tabular}

a. Dependent Variable: ROE

Sumber : Hasil pengolahan data dengan program SPSS 17.0

Berdasarkan tabel hasil pengujian hipotesis secara parsial yang telah dilakukan dengan menggunakan program SPSS versi 17.0 di atas, nilai regresi Current Ratio pada hasil regresi linear berganda 
sebesar 0,063, yang artinya Current Ratio memiliki pengaruh positif terhadap Return On Equity. Jika Current Ratio mengalami peningkatan, maka Return On Equity akan mengalami peningkatan.

Sedangkan dari Hasil uji-t, diperoleh perbandingan thitung dengan $t_{\text {tabeladalah }}-t_{\text {tabel }} \leq t_{\text {hitung }} \leq t_{\text {tabel }}(-2,012 \leq$ $1.866 \leq 2,012)$, sehingga $\mathrm{H}_{0}$ diterima dan $\mathrm{H}_{\mathrm{a}}$ ditolak yang berarti bahwa Current Ratio tidak memiliki pengaruh yang signifikan terhadap Return On Equity pada perusahaan Food and Baverage. Selain itu, dapat dilihat bahwa nilai signifikansi uji $\mathrm{t}$ variabel Current Ratio sebesar 0,068. Karena nilai signifikansinya $>0,05(5 \%)$ taraf signifikansi, maka keputusan yang diambil dengan tingkat signifikansi adalah menerima $\mathrm{H}_{0}$ dan menolak $\mathrm{H}_{a}$ sehingga dapat disimpulkan bahwa variabel Current Ratio tidak memiliki pengaruh yang signifikan terhadap Return On Equity pada perusahaan Food and Baverage. Current ratio tidak memiliki pengaruh yang signifikan terhadap Return On Equity yang mungkin dikarenakan perubahan current ratio yang tidak stabil selama tahun 2012-2016.

Nilai Debt to Equity Ratio regresi pada hasil regresi linear berganda sebesar sebesar 39,381, yang artinya Debt to Equity Ratio memiliki pengaruh positif terhadap Return On Equity. Jika Debt to Equity Ratio mengalami peningkatan, maka Return On Equity juga akan mengalami peningkatan.

Sedangkan dari Hasil uji-t, diperoleh perbandingan thitung dengan $t_{\text {tabel }}$ adalah $t_{\text {hitung }}>t_{\text {tabel }}(5,381>$ 2,012), sehingga $\mathrm{H}_{0}$ ditolak dan $\mathrm{H}_{a}$ diterima yang berarti bahwa Debt to Equity Ratio memiliki pengaruh yang signifikan terhadap Return On Equity pada perusahaan Food and Baverage. Selain itu, dapat dilihat bahwa nilai signifikansi uji t variabel Current Ratio sebesar $0,000 . \quad K a r e n a$ nilai signifikansinya >0,05 (5\%) taraf signifikansi, maka keputusan yang diambil dengan tingkat signifikansi adalah menolak $\mathrm{H}_{0}$ dan menerima $\mathrm{H}_{a}$ sehingga dapat disimpulkan bahwa variabel Debt to Equity Ratio memiliki pengaruh yang signifikan terhadap Return On Equity pada perusahaan Food and Baverage.

\section{F. KESIMPULAN}

1. Berdasarkan hasil pengujian hipotesis secara simultan (uji $\mathrm{F}$ statistik) menunjukkan bahwa variabel Current Ratio dan Debt to Equity Ratio secara bersamasama memiliki pengaruh yang signifikan terhadap Return On Equity perusahaan Food and Baverage yang terdaftar di IDX tahun 2012-2016. Nilai Koefisien Determinasi ( $R$ Square) sebesar 0,417 yang berarti menunjukkan bahwa pengaruh Current Ratio dan Debt to Equity Ratio terhadap Return On Equity perusahaan Food and Baverage yang terdaftar di IDX tahun 20122016 adalah sebesar 41,7\%, sedangkan sisanya sebesar $58,3 \%$ dipengaruhi oleh variabel lain yang tidak disebutkan dalam model penelitian ini.

2. Berdasarkan hasil pengujian hipotesis secara parsial (uji $t$ statistik) menunjukkan bahwa :

a. Variabel Current Ratio dengan tingkat signifikan sebesar $0,068(6,8 \%)$ yang berarti nilainya lebih besar dari taraf signifikansi sebesar 0,05 (5\%). Hal ini menunjukkan bahwa Current Ratio tidak memiliki pengaruh yang signifikan terhadap Return On Equity perusahaan Food and Baverage yang terdaftar di IDX tahun 2012-2016. 
b. Variabel Debt to Equity Ratio dengan tingkat signifikan sebesar $0,000 \quad(0 \%)$ yang berarti nilainya lebih kecil dari taraf signifikansi sebesar 0,05 (5\%). Hal ini menunjukkan bahwa Debt to Equity Ratio memiliki pengaruh yang signifikan terhadap Return On Equity perusahaan Food and Baverage yang terdaftar di IDX tahun 2012-2016.

\section{DAFTAR PUSTAKA}

Aminartuzzahra. (2010). "Analisis pengaruh Current Ratio, Debt to Equity Ratio, Total Asset Turnover, Net Profit Margin terhadap Profitabilitas Return On Equity". Semarang : Skripsi Universitas Diponegoro Semarang : Tidak dipublikasikan.

Anwar Sanusi, (2011), "Metode Penelitian Bisnis", Salemba Empat, Jakarta.

Astuti, Dewi. (2004). "Manajemen Keuangan Perusahaan". Jakarta: Ghalia Indonesia.

Bambang Riyanto. (2010). "DasarDasar Pembelanjaan Perusahaan, ed. 4", Yogyakarta : BPFE.

David Wijaya. (2016). "Praktikum Manajemen Keuangan 1 Berbasis IFRS". Jakarta : Mitra Wacana Media.

Emzir. (2007). "Metodologi Penelitian Pendidikan Kuantitatif dan Kualitatif'. Jakarta: PT Raja Grafindo Persada.
Ghozali, Imam. (2011). "Aplikasi Analisis Multivariate Dengan Program SPSS". Semarang: Badan Penerbit Universitas Diponegoro.

Ghozali, Imam. (2013). "Aplikasi Analisis Multivariate Dengan Program SPSS". Edisi Ketujuh. Semarang: Badan Penerbit Universitas Diponegoro.

Harahap, Sofyan Syafri. (2009). "Analisis Kritis Atas Laporan Keuangan". Jakarta: RajaGrafindo Persada.

Herry (2016). "Analisis Laporan Keuangan". Jakarta: PT. Bumi Aksara.

Ikatan Akuntan Indonesia. (2009). "Standar Akuntansi Keuangan", PSAK No. 1 : Penyajian Laporan Keuangan. Jakarta : Salemba Empat.

James C. Van Horne \& John M. Wachowicz jr. (2012). "Prinsipprinsip Manajemen Keuangan". Edisi 13, buku 1. Jakarta : Salemba Empat.

Kasmir. (2011). "Analisis Laporan Keuangan". Jakarta : PT RajaGrafindo Persada.

Munawir. (2007). "Analisis Laporan Keuangan". Yogyakarta : Edisi Empat, Liberty.

Munawir. (2010), "Analisa Laporan Keuangan". Yogyakarta: Liberty.

Ratna, Nyoman Kutha. (2010). "Metodologi Penelitian: Kajian Budaya dan IImu Sosial Humaniora Pada Umumnya". Pustaka Pelajar : Yogyakarta. 
Riyanto, Bambang, (2008). "DasarDasar Pembelanjaan Perusahaan", Edisi Keempat, Cetakan Kedelapan. Yogyakarta: BPFE.

Sa'i, Kamsrin. dkk. (2014). "Pedoman Penulisan Skripsi Dan Laporan Akhir". Palembang : Fakultas Ekonomi Universitas Tridinanti Palembang.

Santosa, Debora. Setiati. (2009). "Analisis Current Ratio, Total Asset Trunover, dan Debt to Equity Ratio terhadap Return on Equity". Semarang : Skripsi Universitas Diponegoro Semarang : Tidak dipublikasikan.

Sari, Novita. (2015). "Analisis pengaruh Current Ratio, Debt to Equity Ratio terhadap Profitabilitas Return On Equity". Surabaya : Universitas Wijaya Putra Surabaya : Tidak dipublikasikan.

Sofyan Syafri Harahap. (2011). "Analisis Kritis Atas Laporan
Keuangan". Jakarta: Raja grafindo Persada.

Sugiyono, (2008), "Metode Penelitian Kuantitatif, Kualitatif dan R\&D", Bandung : Alfabeta.

Sugiyono, (2009), "Metode Penelitian Kuantitatif, Kualitatif dan R\&D", Bandung : Alfabeta.

Sugiyono. (2012). "Metode Penelitian Kuantitatif Kualitatif dan R\&D". Bandung: Alfabeta.

Sujarweni, Wiratna. (2017). "Analisis Laporan Keuangan". Yogyakarta : Pustaka Baru Press.

Sutrisno. (2008). "Manajemen Keuangan". Yogyakarta : Ekonesia.

Utama, M. (2012),"Hukum Ekonomi Internasional". Jakarta: PT. Fikahati Aneska.

www.idx.co.id. (2017). Laporan Kuangan Perusahaan Manufaktur yang Terdaftar di IDX. 